\title{
Financial sector development and smart cities: The Indian Case
}

\section{Introduction}

Smart city is a multidimensional concept and its definition varies considerably in the literature (Albino et al. 2015; Neirotti et al. 2014). While some studies focus on ICT, others focus on governance and people. Bakici, Almirall and Wareham (2013) defined smart city as, "those cities that utilise information and communication technologies with the aim to increase the life quality of their inhabitants while providing sustainable development". Anttiroiko et al. (2014) argue that "smart city concept reflects a particular idea of local community, one where city governments, enterprises and residents use ICTs to reinvent and reinforce the community's role in the new service economy, create jobs locally and improve the quality of community life". According to Haque (2012) "Smart cities cannot be defined by one application, or central organizing body, that sets pre-programmed limits. They will be defined by individual citizens, who are anxious to collaborate with each other to create devices and applications that solve specific problems. Smart cities will be places that foster creativity, where citizens are generators of ideas, services and solutions, rather than passive recipients of them". Different dimensions of smart city can be observed from the definitions above. The Indian policy makers argue "there is no universally accepted definition of a smart city. It means different things to different people. The conceptualisation of Smart City, therefore, varies from city to city and country to country, depending on the level of development, willingness to change and reform, resources and aspirations of the city residents" (Government of India 2016).

India recently introduced Smart Cities Mission "to drive economic growth and improve the quality of life of people by enabling local area development and harnessing technology, especially technology that leads to Smart outcomes" (Government of India 2016). All in all 100 cities have been targeted under this mission covering the period 2015-16 to 2019-20. ${ }^{1}$

A smart city, according to the Indian smart city mission, should have adequate water supply, assured electricity supply; sanitation facilities; affordable housing; IT connectivity; good

\footnotetext{
${ }^{1}$ See Hoelscher (2016) for socio-political dimensions on the evolution of smart cities in India.
} 
governance including e-governance; sustainable environment; safety and security of the citizens and health and education of the residents. Globally as well, the agenda has centered on management and organisation, technology, governance, people, economy, ICT infrastructure and natural environment (Chourabi et al. 2012; Neirotti et al.2014).

Although not discussed in the existing literature and also not a part of the Indian agenda, a smart functional city also needs an efficient and inclusive financial system. An efficient and inclusive financial system allows "people to invest in business, education and their health, increases consumption and overall wellbeing. It is considered as a critical factor in job creation and promotion of economic growth" (Arora 2017). Sarma and Pais (2011) argue that "an all-inclusive financial system enhances efficiency and welfare by providing avenues for secure and safe saving practices and by facilitating a whole range of efficient financial services." Other studies too have noted positive relationship between households' and firms access to finance and economic growth (Imboden 2005; Sahay et al. 2015; Dabla-Norris et al. 2015; Zhang and Posso 2017). It is also an integral part of the Sustainable Development Goals wherein financial access is considered crucial to the achievement of several SDG goals. For instance, the UN Sustainable Development Goals recommend to "strengthen productive capacity by providing universal access to financial services and infrastructure such as transportation and ICT' to achieve Goal 8 of creating jobs, sustainable livelihoods and equitable growth" (see UN 2013).

An efficient financial system is needed for the creation of smart city as was highlighted by Huston et al. (2015). The channels through which various functions of financial sector contribute to growth in general, according to Levine (1997), are accumulation of capital and technological innovation. In the smart cities discourse where emphasis is more on the adoption of cutting edge technology, new business activity and technological spurts can take place if the financial system is adequately developed. Even in developed countries inadequate availability of financial services has set constraints to the growth of smart cities. For instance, some of the challenges faced by Barcelona city, considered as a leading metropolis of Europe and a model of smart city, include inadequate financial development which has impacted its ability to attract new firms and start-ups (Bakici et al. 2013). This is even more challenging for developing countries which have less developed financial systems including low access to finance. According to the Global Financial Inclusion database, 2014 only $27.5 \%$ and $42.7 \%$ 
of adult population had bank accounts in low income countries and low middle income countries respectively in contrast to $90.6 \%$ in high income countries.

Further, availability of financial services can lead to the provision of credit for housing purposes, assist in building urban infrastructure (Huston, Rahimzad \& Parsa 2015), smoothen health expenses especially in the absence of a robust public health care system and facilitate education. Human development is an important dimension of smart city development as Oliveira and Campolargo, (2015) argue that although technology is an important dimension of smart city, it is the people behind it who are the "true actors of the urban "smartness". Neirotti et al. (2014) reiterate that ICT and human capital development are complementary in smart cities initiative and not substitutes of each other. Winters (2011) argues that highly educated people are one of the key actors in smart cities growth. Studies have also shown that cities with higher skilled people have better employment opportunities and this concentration of skills also impacts quality of life (Shapiro 2006). Availability of finance can play a crucial role in building this human capital and contribute to smart city development. Flug et al. (1998) also show that low financial development has a negative impact on the accumulation of human capital.

Furthermore, a smart city initiative which is largely based on smart technological and innovative solutions should ideally also have a smart technologically developed financial sector which is both efficient and inclusive. Digital finance or different financial technologies such as digital KYC (Know Your Customer), mobile phones, alternative data for credit scoring, peer to peer lending, cloud, block chain technology increase financial inclusion (Radcliffe and Voorhies 2012). According to Gomber et al. (2017) "digital finance encompasses a magnitude of new financial products, financial businesses, finance-related software, and novel forms of customer communication and interaction-delivered by FinTech companies and innovative financial service providers". More closely "it entails all electronic products and services of the financial sector e.g., credit and chip cards, electronic exchange systems, home banking, and home trading services... as well as automated teller machines. Furthermore it involves all mobile and app services". Huston et al. (2015) argue that "SmartSUR rests on a credible corporate structures, strong public-private alliances, sound geographic context, and financial credibility. Disruptive alternative financing technologies like 'crowd - funding' and 'digital currencies' such as Bitcoin, could revolutionise the sector." Crowd funding allows new enterprising start-ups to establish by appealing directly to the crowd of investors (Dapp 2014). These financial technological innovations not only allow 
new innovative activities in smart cities to take place which it professes but also increase financial inclusion of different groups of population.

Moreover, of the 17 sustainable development goals (SDGs) at least seven have identified financial inclusion as a core requisite for the achievement of SDGs. G20 has also committed to implementing High Level Principles for Digital Financial Inclusion. Starting from digital KYC documents, providing last mile solution in reaching out to the hard to reach population; providing affordable products and services and robust financial security platforms digital finance allows increased financial inclusion. It reaches out to new customers overlooked by the traditional banking system as it provides credit to small and medium enterprises; and also leads to increased savings by the government by preventing leakages in the payment of welfare benefits thereby allowing increased availability of funds for productive expenditure. Many digital financial products such as digital credit through ICT are innovative, cost efficient and provide smart solutions to the problems of small businesses, small borrowers and can meet the financial needs of those underbanked or overlooked by the traditional financial institutions (Gomber et al. 2017; Francis et al. 2017).

This author has not come across any study which has sensitised the need for development of inclusive financial sector in the development of smart cities. The financing aspect of a smart city is often discussed in terms of how smart cities could be financed (Belissent 2010; Cosgrave et al. 2013; Vadgama et al. 2015 for India; Smart Cities Stakeholder Platform 2013 for EU; Li et al. 2015 for China; Cruz and Sarmento 2017), but the discussion on how people residing within the smart city could access finance is often missing in the smart city literature and policy deliberations.

This study aims to fill in this gap in the current literature on smart cities and examines existing financial sector development of selected smart cities in the Indian context. A major research question which this study seeks to examine is: what is the level of financial development in these cities? Are these cities financially well developed? How digitization of financial services can contribute to the development of smart cities? To this end, the study develops a composite financial services index for the cities under consideration based on the data available from Reserve Bank of India (RBI) and Census 2011. Rest of the study is organised as follows. Section 2 provides a snapshot of the related literature and highlights the important role played by finance in local development. Next section provides a brief 
background of smart city project in India. Section 4 builds financial services index and provides methodology and results. The last section of the study concludes.

\section{Related literature}

The broader literature on finance and its role in development has shown positive relationship between financial development and economic growth (Levine 1997). Besides the studies at cross-country and national level, several other studies have also emphasised the importance and necessity of financial development at the local level. Local financial development matters as it leads to increase in credit as the distance to bank branches is reduced, leads to increased savings and promotes higher economic growth (Petersen and Rajan 2002; Guiso, Sapienza and Zingales 2004; Jayaratne and Strahan 1996; Lucchetti et al; Thangavelu et al. 2004; Vaona 2008). Bodernhorn and Cuberes (2014) in a study for $19^{\text {th }}$ century US showed that households and firms consumption and production was higher in those cities which had banking facilities than those without banks. Guiso, Sapienza and Zingales (2004) study the impact of local financial development on households and firms. Their findings show that financial development allows setting up of new businesses and entry of new firms which leads to increased competition and promotes economic growth. Interestingly these effects are higher for the small firms compared to large ones. Jayaratne and Strahan (1996) found for the US states that increased deregulation of bank branches increased competition and promoted growth and investment.

Inclusive financial systems by providing access to financial services to different groups of population contribute to the economic growth of local areas. Zhang and Posso (2017) showed that financial inclusion has a positive impact on households' income and leads to reduction in inequality. Dabla-Noriss et al. (2015) in their study identify three main barriers to financial inclusion- barriers of accessing credit due to high costs and documentation requirements; barriers of high collateral requirements leading to lack of credit; and barriers of high interest costs reflecting the problem of asymmetric information between lenders and borrowers. Removal of these constraints leads to inclusion of small firms in the financial system which in turn triggers start of new businesses, start-ups and has a positive impact on GDP growth and productivity. 
Few studies exist on financial development and cities. Fafchamps and Schundeln (2013) at the commune level (similar to cities) in the context of Morocco explore whether local financial development matters for local firms. Results of the study show that firms located close to banks experienced faster growth. The authors argue that Morocco has low bank density and banks are absent in many communes. Availability of banks had a positive impact on firm growth, particularly for medium firms. Also such firms which are able to access financial services from local banks invest more and hire workers. D'Onofrio and Murro (2013) examined the impact of local financial development on inequality. They examined this in the context of 103 provinces in Italy for the period 2006-2010. Their study indicates that local financial development matters for a number of reasons. The results of their study indicate significant negative relationship between local banking development and Gini coefficient indicating that higher banking development is associated with lower inequality.

Pan and Yang (2018) explored startups entrepreneurial activity and role of financial sector in promoting startup businesses. The main research question of the study is what role the financial sector plays in attracting new innovative activities to take place. Examining the location of over 5081 startups in China spread over 221 cities, the study notes that high financial development- equity and credit financing and availability of venture capital has a positive influence on the location of startups. The study also finds that the size of financial centers also impact the startups location. The study in their model besides financial development also considers human capital; presence of universities, overall economic development; unemployment rate, infrastructure such as availability of internet.

That cities positively influence financial development which in turn leads to city economic growth was confirmed by Becker (2006). Becker (2006) showed that size of a city measured in terms of population has a positive impact on the stock market development. Terming it as agglomeration theory of financial development the findings of his study show that similar effect do not persist for banking sector though, as they are more widely dispersed.

Destefanis, Barra and Lavadera (2014) examine data at a disaggregated level that is at SLL level (Sistema Locale del Lavoro or a group of municipalities) from Italy. Employing qualitative and quantitative indicators - bank profit efficiency score and aggregate credit by banks to non-financial institutions for the period 2001 to 2010, the results suggest that financial development has a positive impact on region's output. 
The questions which emerge here are the smart cities which are based primarily on the idea of technology promoting innovative enterprises; are they able to nurture and foster startup innovative activities? Do these cities have financial sector which can lead to thriving startups? This leads us even to a more basic question - do these cities have adequate level of financial services? What is the existing state of their financial sector?

\section{Smart cities in India - brief background}

The smart cities mission in India covers 100 (initially 20 shortlisted cities) cities for the period 2015-16 to 2019-20 launched by the Ministry of Urban Development. The selection of cities is on the basis of equitable criteria with equal weightage (50:50) to urban population and number of statutory towns in the state. The names of the initially 20 smart cities selected by the government are given below:

Table 1: Twenty Smart Cities in India

\begin{tabular}{ccc}
\hline No. & Cities & States \\
\hline 1 & Bhubaneshwar & Odisha \\
2 & Pune & Maharashtra \\
3 & Jaipur & Rajasthan \\
4 & Surat & Gujarat \\
5 & Kochi & Kerala \\
6 & Ghmedabad & Gujarat \\
7 & Jabalpur & Madhya Pradesh \\
8 & Vishakhapatnam & Andhra Pradesh \\
9 & Solapur & Maharashtra \\
10 & Davangere & Karnataka \\
11 & Indore & Madhya Pradesh \\
12 & NDMC & New Delhi \\
13 & Coimbatore & Tamilnadu \\
14 & Kakinada & Andhra Pradesh \\
15 & Udaipur & Rajasthan \\
16 & Guwahati & Assam \\
17 & Chennai & Tamil Nadu \\
18 & Ludhiana & Punjab \\
19 & Bhopal & Madhya Pradesh \\
20 & Belagavi & Karnataka \\
\hline
\end{tabular}

Source: Government of India, Smart Cities Mission.

The objectives of smart city mission in India are to develop cities that provide core infrastructure; provide decent quality of life to its citizens; are environment friendly and 
overall focus on sustainable and inclusive development. Although all the above cities have been shortlisted under a uniform smart city project, yet the differences across the cities are stark in term of availability of infrastructure facilities, economic development, social development, and availability of household assets.

Table 2 shows availability of assets at the household level in the selected cities. It shows considerable variations across the cities particularly in internet connectivity and ownership of large vehicles. The proportion of households with internet facilities was just $4.1 \%$ in Solapur and highest $27.7 \%$ in the Delhi region. In contrast the proportion of households owning mobile phones, on an average, across all the cities was much higher at $64.1 \%$.

Table 2: Percentage of households owning assets

\begin{tabular}{|c|c|c|c|c|c|c|c|c|c|c|c|c|c|}
\hline \multicolumn{14}{|c|}{ Percentage of Households } \\
\hline & $\begin{array}{l}\text { Total no. } \\
\text { of } \\
\text { households } \\
\text { availing } \\
\text { banking } \\
\text { services }\end{array}$ & $\begin{array}{l}\text { Radio/ } \\
\text { Transist } \\
\text { or }\end{array}$ & Television & $\begin{array}{l}\text { With } \\
\text { Internet }\end{array}$ & $\begin{array}{l}\text { Without } \\
\text { Internet }\end{array}$ & $\begin{array}{l}\text { Telepho } \\
\text { Landlin } \\
\text { Only }\end{array}$ & $\begin{array}{l}\text { Mobile } \\
\text { only }\end{array}$ & phone & $\begin{array}{l}\text { Bicy } \\
\text { cle }\end{array}$ & $\begin{array}{l}\text { Scoo } \\
\text { ter/ } \\
\text { Mop } \\
\text { ed }\end{array}$ & $\begin{array}{l}\text { Car/ } \\
\text { Jeep/ } \\
\text { Van }\end{array}$ & $\begin{array}{l}\text { Households } \\
\text { with } \\
\text { TV/Comput } \\
\text { er/Laptop }\end{array}$ & $\begin{array}{l}\text { None } \\
\text { of } \\
\text { assets }\end{array}$ \\
\hline 1 & 2 & 3 & 4 & 5 & 6 & 7 & 8 & 9 & 10 & 11 & 12 & 13 & 14 \\
\hline Bhubaneshwar & 72.5 & 24.7 & 71.0 & 16.0 & 14.8 & 5.2 & 64.7 & 14.3 & 61.1 & 54.3 & 14.3 & 25.2 & 5.7 \\
\hline Pune & 83.9 & 41.2 & 84.4 & 16.5 & 15.9 & 7.6 & 70.2 & 14.1 & 33.0 & 54.4 & 17.2 & 26.3 & 3.2 \\
\hline Jaipur & 73.3 & 41.1 & 84.2 & 12.4 & 13.8 & 5.7 & 66.1 & 18.1 & 42.8 & 59.6 & 19.7 & 22.4 & 3.6 \\
\hline Surat & 53.5 & 33.3 & 66.1 & 5.1 & 8.1 & 3.2 & 71.4 & 7.8 & 30.8 & 44.1 & 8.6 & 10.3 & 8.4 \\
\hline Kochi & 82.7 & 42.1 & 93.6 & 20.9 & 14.9 & 6.9 & 54.1 & 34.8 & 39.1 & 45.6 & 23.9 & 27.5 & 1.0 \\
\hline Ahmedabad & 71.0 & 38.0 & 83.5 & 10.3 & 11.4 & 5.8 & 62.5 & 15.7 & 48.7 & 52.5 & 13.7 & 18.6 & 4.9 \\
\hline Jabalpur & 64.5 & 24.5 & 77.8 & 7.0 & 11.4 & 5.9 & 57.2 & 9.8 & 60.1 & 45.6 & 8.5 & 14.1 & 7.9 \\
\hline Vishakhapatnam & 64.0 & 24.2 & 83.5 & 8.9 & 11.4 & 5.6 & 66.9 & 10.0 & 24.9 & 38.2 & 8.6 & 14.2 & 5.9 \\
\hline Solapur & 64.0 & 22.1 & 70.7 & 4.1 & 8.5 & 5.8 & 61.3 & 7.9 & 52.5 & 32.8 & 4.9 & 8.1 & 10.4 \\
\hline Davangere & 53.3 & 12.4 & 79.8 & 4.3 & 12.4 & 6.6 & 65.4 & 6.9 & 37.0 & 31.8 & 6.5 & 9.1 & 7.4 \\
\hline Indore & 66.8 & 37.1 & 83.9 & 10.2 & 12.0 & 6.7 & 63.7 & 12.6 & 54.2 & 50.2 & 12.6 & 18.1 & 4.2 \\
\hline NDMC & 88.6 & 40.5 & 89.3 & 27.7 & 16.5 & 6.1 & 62.7 & 24.7 & 34.6 & 36.7 & 27.9 & 32.9 & 2.4 \\
\hline Coimbatore & 64.0 & 31.0 & 90.6 & 8.4 & 10.5 & 5.8 & 69.7 & 11.0 & 37.3 & 49.6 & 10.8 & 14.3 & 2.8 \\
\hline Kakinada & 54.1 & 10.1 & 77.4 & 6.1 & 9.4 & 5.3 & 57.5 & 8.5 & 52.3 & 31.9 & 5.1 & 9.6 & 8.8 \\
\hline Udaipur & 79.3 & 31.4 & 82.9 & 10.2 & 12.7 & 6.2 & 62.0 & 19.4 & 35.5 & 66.2 & 16.6 & 19.8 & 5.2 \\
\hline Guwahati & 84.7 & 37.7 & 79.6 & 12.1 & 21.7 & 5.7 & 77.3 & 8.5 & 24.5 & 30.6 & 19.9 & 20.4 & 3.7 \\
\hline Chennai & 71.1 & 36.0 & 95.4 & 19.6 & 12.5 & 10.3 & 62.3 & 19.3 & 37.0 & 46.6 & 13.2 & 23.9 & 1.0 \\
\hline Ludhiana & 64.8 & 18.2 & 85.1 & 11.1 & 10.8 & 6.9 & 64.6 & 14.6 & 56.3 & 50.1 & 18.5 & 18.3 & 3.6 \\
\hline Bhopal & 67.8 & 29.4 & 77.1 & 10.1 & 12.8 & 5.9 & 61.3 & 11.0 & 34.4 & 48.3 & 14.5 & 18.3 & 7.6 \\
\hline Belagavi & 67.1 & 17.1 & 73.1 & 5.2 & 10.2 & 6.3 & 61.3 & 10.6 & 46.9 & 36.3 & 7.3 & 9.8 & 8.5 \\
\hline Average & 69.6 & 29.6 & 81.5 & 11.3 & 12.6 & 6.2 & 64.1 & 14.0 & 42.2 & 45.3 & 13.6 & 18.1 & 5.3 \\
\hline SD & 10.3 & 10.0 & 7.7 & 6.2 & 3.1 & 1.3 & 5.3 & 6.8 & 11.2 & 9.9 & 6.3 & 6.9 & 2.7 \\
\hline $\mathrm{CV}$ & 14.8 & 33.7 & 9.4 & 54.5 & 24.8 & 21.2 & 8.3 & 48.7 & 26.5 & 22.0 & 46.3 & 38.4 & 51.4 \\
\hline
\end{tabular}

Source: Census 2011.

Differences exist across the cities in their per capita incomes as well as the figure below shows. Udaipur's per capita income is merely $21 \%$ of that of New Delhi or just $27 \%$ of the next largest city, Pune. The average per capita income of these shortlisted cities is Rs.50,620 (approximately US\$790), but around half of them fall below the average incomes. 


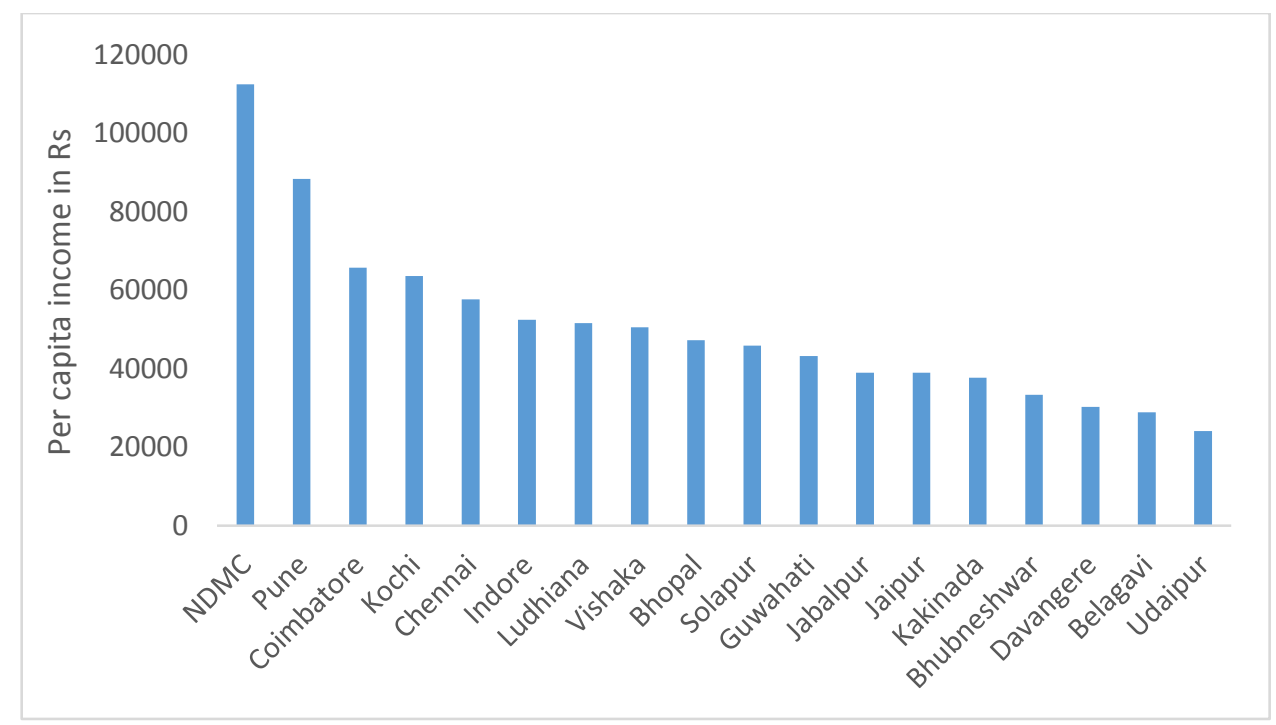

Figure 1: Per capita incomes of smart cities

The financial development of these cities varies considerably with some cities reporting high presence of bank branches while others lag (Figure 2). These also reflect inter-state differences in the level of economic development. For instance, Chennai with the highest presence of bank branches is located in the relatively prosperous and developed state of Tamilnadu. At the other end, is Davangere located in the relatively developed southern state of Karnataka, a state which also hosts Bangalore known as the IT hub of India, thus depicting a picture of high intra-state inequality.

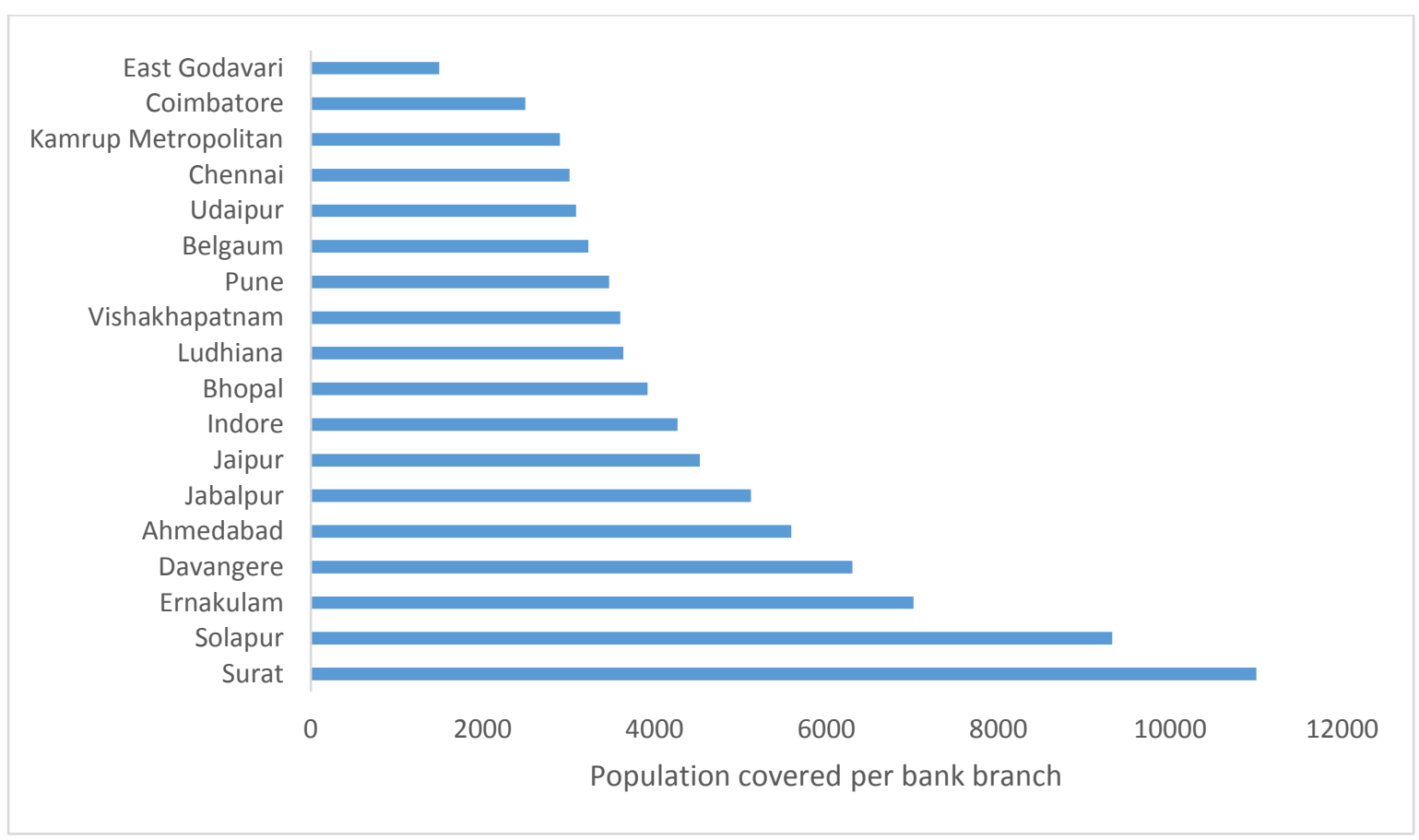

Figure 2: Population covered per bank branch 


\section{Financial Services Index}

In order to examine our major research question- the extent of current financial development in the selected smart cities in India, we build a multidimensional financial services index. As there is no single indicator of financial sector development, different studies have followed different approaches for instance some choose to focus on a specific indicator like M2 or M3/GDP or ratio of private sector credit to GDP, while others have built composite indices taking into account a variety of indicators (Ang and McKibbin 2005; Svirydzenka 2016; Arora 2012). The financial sector is, however, diverse and multidimensional for instance, in Čihák, Demirgüç-Kunt, Feyen, and Levine's study (2013) different dimensions of financial development are outreach, size, depth, stability and access to finance. Svirydzenka (2016) in her study takes into account the dimensions of depth, access and efficiency. In this study following the latter approach, we build a composite financial services index focusing on the dimensions of access and depth of financial sector development. As stated earlier, our objective here in building this index is to capture the state of existing financial sector of these smart cities.

\subsection{Methodology}

We denote each dimension by $D_{j}$ where $\mathrm{j}=1 \ldots \mathrm{J}$, and therefore $\mathrm{J}=3$. Each dimension consists of n number of determinants which we denote by $X_{i}$, and $i=1$..n. First, we compute the value $X_{i}$ for each dimension $j$ as follows.

$$
X_{i j}=\frac{X_{i j a}-X_{i j m}}{X_{i j u}-X_{i j m}}
$$

Here, the notations $X_{i j a}, X_{i j m}$ and $X_{i j u}$ respectively represent the actual observed value, minimum value and maximum value for $i^{\text {th }}$ determinant in $j^{\text {th }}$ dimension. The minimum and maximum values, termed as 'goalposts' (UNDP, 2009), are the minimum and maximum value of each variable in different states. Now we use the simple arithmetic average as follows to determine the value for each Dimension $D_{j}$.

$$
D j=\frac{\sum_{i=1}^{n} X_{i j}}{n}
$$


Next, we assign weights (denoted by $\alpha_{j}$ for dimension $j$ to each dimension). We compute the financial services index (FSI) for each smart city as follows.

$$
F S I=\sum_{j=1}^{J} \alpha_{j} D_{j}
$$

The index covers the years 2007 to 2016 and the data has been sourced from annual publications of Reserve Bank of India. The variables covered are number of offices, number of accounts, amount outstanding of deposit and outstanding amount of credit. We group these variables under two broad dimensions- access and usage where number of bank branch branches and number of accounts indicate access to financial services; deposit and credit amount outstanding display pickup of financial services. We are constrained by choice of variables as at the district level data is not available for many variables. Data on two citiesNew Delhi Municipal Corporation (NDMC) and Bhubaneshwar (Odisha) is not available in the RBI publications. We therefore, focus on 18 smart cities spread over 10 states which are at different stages of development. RBI data is, however, based on Census 2001, names of some of the smart cities, therefore, does not exactly match with those announced by the government. For instance, Kochi as in the Smart cities Mission, in RBI publications the data is however, available for Ernakulum district. Another smart city announced by the Government in 2016 is Kakinada, RBI/Census data is, however, available for East Godavari district. We focus only on the metropolitan/urban centres which approximately covers the cities as defined under the mission. Metropolitan group under the RBI nomenclature refers to centres with population of 1 million and more.

\subsection{Results}

Table 3 shows financial services index constructed for 18 selected smart cities. As mentioned earlier, the index for each year is developed combining the dimensions of access and usage.

On an average, Chennai ranks highest among all the cities in financial services index followed by Ahmedabad and Pune. These three cities are located in the more developed states- Tamilnadu, Gujarat and Maharashtra. At the bottom end are Udaipur (Rajasthan); Solapur (Maharashtra) and Davangere (Karnataka). Although Solapur and Davangere are located in more prosperous and developed states, a high intra-state inequality exists across the Indian states. For instance, credit-deposit ratio of Mumbai (suburban), the financial capital of India and capital of Maharashtra is one and half times more than that of Solapur (urban). 
Studies have observed widening of intra-state inequality both in developed and lagging states and have noted growing divergence across the districts within the states (Naranapanawa and Arora 2014).

Table 3: Financial Services Index in Smart Cities (2007-2016)

\begin{tabular}{lllllllllllll}
\hline Cities & $\mathbf{2 0 0 7}$ & $\mathbf{2 0 0 8}$ & $\mathbf{2 0 0 9}$ & $\mathbf{2 0 1 0}$ & $\mathbf{2 0 1 1}$ & $\mathbf{2 0 1 2}$ & $\mathbf{2 0 1 3}$ & $\mathbf{2 0 1 4}$ & $\mathbf{2 0 1 5}$ & $\mathbf{2 0 1 6}$ & AVG & Ranking \\
\hline Chennai & 1.000 & 1.000 & 1.000 & 1.000 & 1.000 & 1.000 & 1.000 & 1.000 & 1.000 & 1.000 & 1.000 & 1 \\
Ahmedabad & 0.456 & 0.478 & 0.490 & 0.490 & 0.483 & 0.491 & 0.516 & 0.531 & 0.563 & 0.571 & 0.507 & 2 \\
Pune & 0.418 & 0.428 & 0.430 & 0.445 & 0.442 & 0.461 & 0.486 & 0.502 & 0.531 & 0.554 & 0.470 & 3 \\
Jaipur & 0.249 & 0.260 & 0.269 & 0.275 & 0.279 & 0.282 & 0.289 & 0.281 & 0.302 & 0.284 & 0.277 & 4 \\
Coimbatore & 0.222 & 0.220 & 0.211 & 0.160 & 0.156 & 0.157 & 0.276 & 0.160 & 0.166 & 0.165 & 0.189 & 5 \\
Ludhiana & 0.175 & 0.180 & 0.180 & 0.177 & 0.176 & 0.168 & 0.297 & 0.172 & 0.176 & 0.178 & 0.188 & 6 \\
Ernakulam & 0.185 & 0.176 & 0.185 & 0.188 & 0.195 & 0.177 & 0.178 & 0.173 & 0.175 & 0.177 & 0.181 & 7 \\
Bhopal & 0.146 & 0.155 & 0.152 & 0.164 & 0.169 & 0.173 & 0.187 & 0.191 & 0.225 & 0.209 & 0.177 & 8 \\
Indore & 0.158 & 0.157 & 0.156 & 0.159 & 0.158 & 0.161 & 0.161 & 0.162 & 0.173 & 0.189 & 0.163 & 9 \\
Surat & 0.128 & 0.131 & 0.137 & 0.143 & 0.146 & 0.153 & 0.158 & 0.164 & 0.180 & 0.185 & 0.152 & 10 \\
Vishakhapatnam & 0.109 & 0.113 & 0.110 & 0.109 & 0.105 & 0.129 & 0.135 & 0.138 & 0.150 & 0.160 & 0.126 & 11 \\
Kamrup & & & & & & & & & & & & \\
Metropolitan & 0.092 & 0.091 & 0.093 & 0.092 & 0.091 & 0.104 & 0.108 & 0.109 & 0.113 & 0.114 & 0.101 & 12 \\
Jabalpur & 0.060 & 0.056 & 0.057 & 0.058 & 0.059 & 0.058 & 0.058 & 0.058 & 0.060 & 0.064 & 0.059 & 13 \\
East Godavari & 0.055 & 0.057 & 0.059 & 0.057 & 0.057 & 0.056 & 0.059 & 0.057 & 0.058 & 0.057 & 0.057 & 14 \\
Belgaum & 0.039 & 0.038 & 0.037 & 0.036 & 0.037 & 0.037 & 0.037 & 0.036 & 0.035 & 0.033 & 0.036 & 15 \\
Udaipur & 0.033 & 0.039 & 0.037 & 0.035 & 0.036 & 0.037 & 0.037 & 0.033 & 0.037 & 0.035 & 0.036 & 16 \\
Solapur & 0.017 & 0.016 & 0.016 & 0.018 & 0.019 & 0.019 & 0.020 & 0.021 & 0.022 & 0.022 & 0.019 & 17 \\
Davangere & 0.000 & 0.000 & 0.000 & 0.000 & 0.000 & 0.000 & 0.000 & 0.000 & 0.000 & 0.000 & 0.000 & 18 \\
\hline
\end{tabular}

Source: Computed by the author.

The figure below displays relationship between per capita income of the smart cities and financial sector development. By and large, cities with low per capita incomes also have low financial development. 


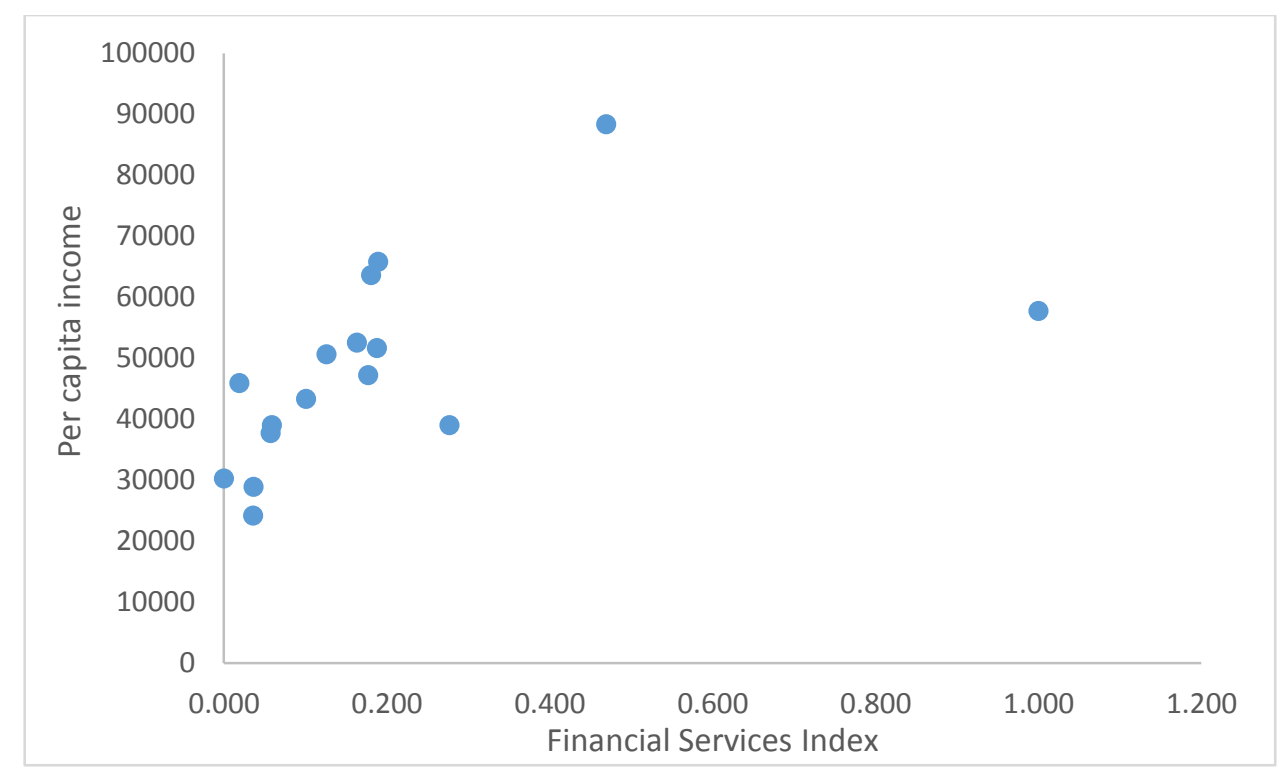

Figure 3: Relationship between FSI and per capita income of smart cities

We further group the cities into three categories based on their FSI index values. Those with average FSI values greater than 0.5 are classified as high financially developed cities (two cities); those with FSI values greater than 0.1 and less than 0.5 termed as cities with medium financial development (10 cities) and finally cities with FSI less than 0.1 are grouped as those with low financial development (six cities). Figure 4 shows financial development of smart cities over time categorised into high, medium and low groups. The figure shows significant gap between cities with high development and medium financial development.

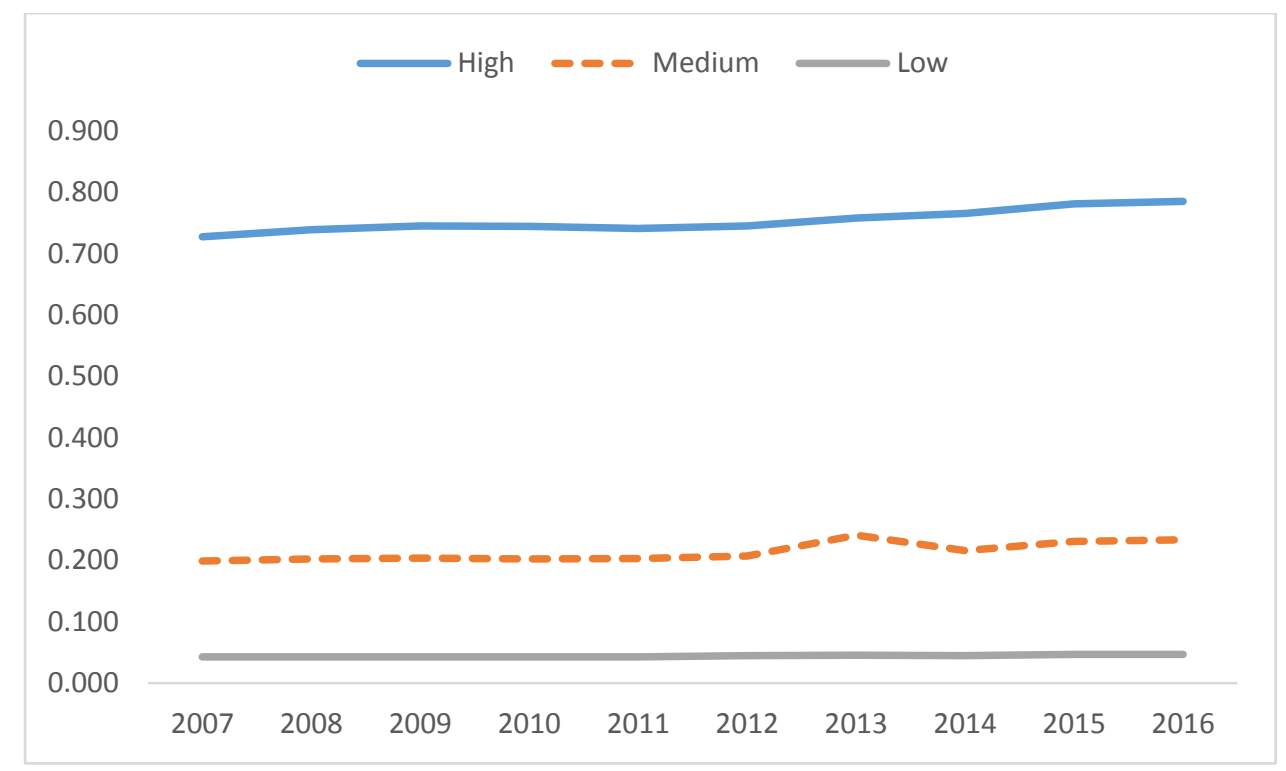




\section{Figure 4: Financial development through time}

Substantial differences also exist across the cities in credit disbursement across different occupations. For instance, the proportion of credit to industrial sector in Davangere, located in the relatively developed state Karnataka is approximately five times lesser than that of Ahmedabad located in Gujarat (Figure 5). Similarly, credit for wholesale and retail trade in these cities ranged from $4.8 \%$ to $28.9 \%$ (Figure 6). The data on occupational credit is however, available only for total credit (that is, it includes credit to rural, semi-urban, and metropolitan regions) to a specific occupation and further breakdown of the occupation or specific population group is not available.

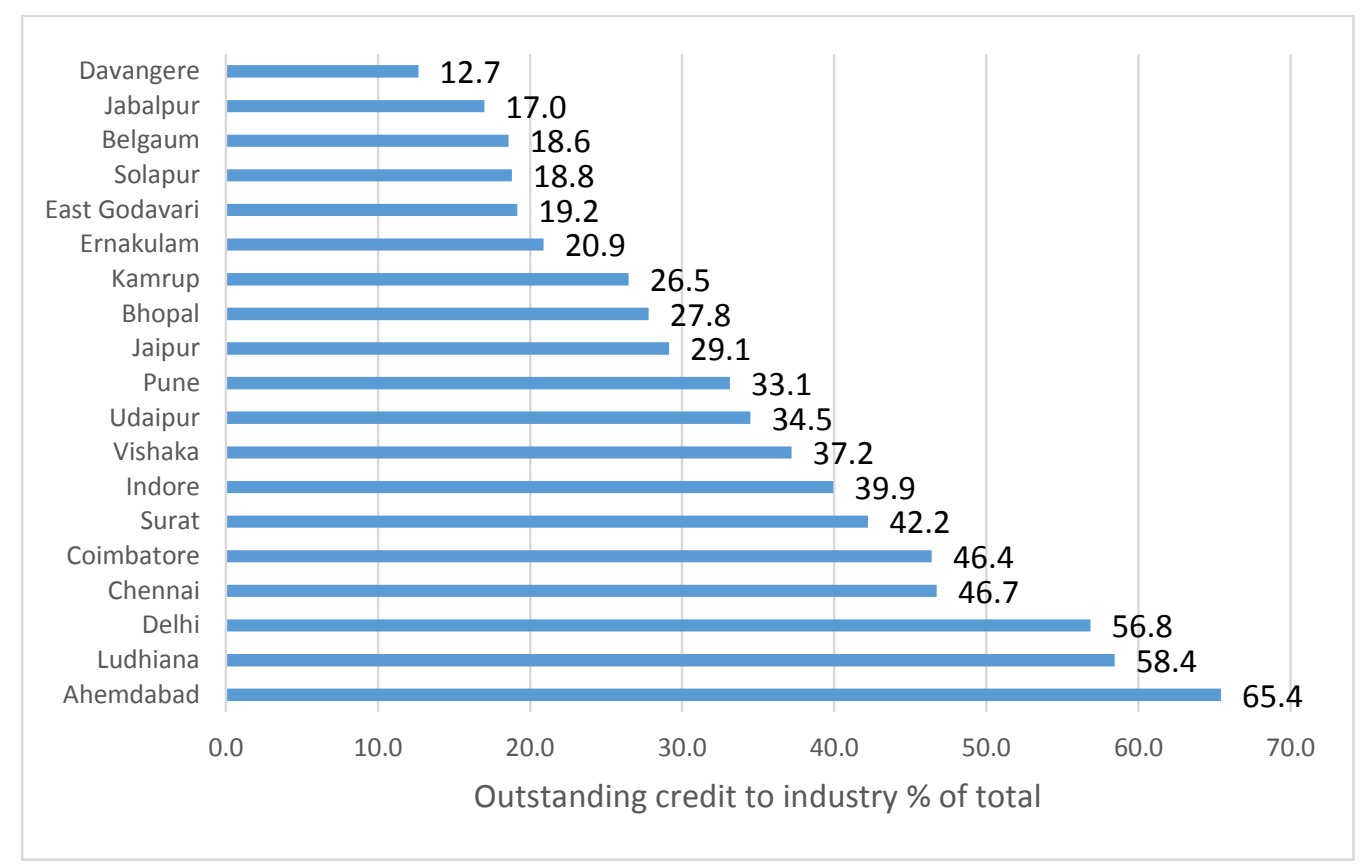

Figure 5: Outstanding credit to industry 


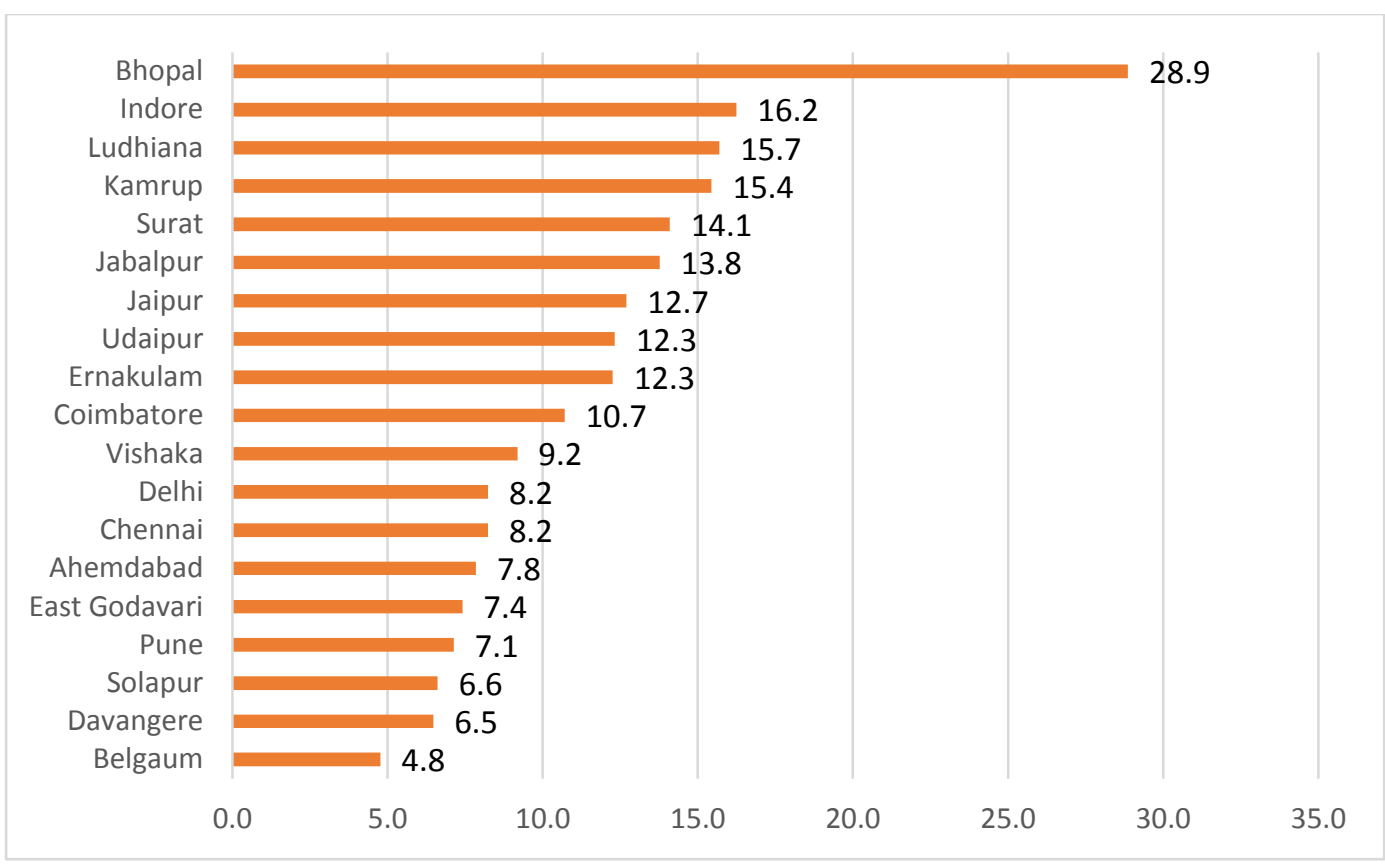

Figure 6: Outstanding Credit to trade

The regional grouping of the 20 smart cities and their ranking in financial services index is shown in Table 4 below. This shows a mixed picture as although the western region and southern regions are more developed, yet they house cities at the extreme ends, in other words cities ranking in the top profile and also those with lower rankings. Even other regions show a similar trend.

Table 4: Regional grouping of 20 Smart Cities

\begin{tabular}{|c|c|c|c|c|c|c|c|c|c|}
\hline Western & $\begin{array}{c}\text { Ranking in } \\
\text { FSI }\end{array}$ & Southern & $\begin{array}{l}\text { anking in } \\
\text { FSI }\end{array}$ & North-East & $\begin{array}{c}\text { Ranking } \\
\text { in FSI }\end{array}$ & North & $\begin{array}{c}\text { Ranking } \\
\text { in FSI }\end{array}$ & Central & $\begin{array}{c}\text { Ranking in } \\
\text { FSI }\end{array}$ \\
\hline Ahmedabad & 2 & Chennai & 1 & $\begin{array}{l}\text { Kamrup } \\
\text { Metro }\end{array}$ & 12 & Jaipur & 4 & Bhopal & 8 \\
\hline Pune & 3 & Coimbatore & 5 & & & Ludhiana & 6 & Indore & 9 \\
\hline Surat & 10 & Ernakulam & 7 & & & Udaipur & 16 & Jabalpur & 13 \\
\hline \multirow[t]{4}{*}{ Solapur } & 17 & Vishakhapatnam & 11 & & & & & & \\
\hline & & East Godavari & 14 & & & & & & \\
\hline & & Belgaum & 15 & & & & & & \\
\hline & & Davangere & 18 & & & & & & \\
\hline
\end{tabular}

Source: Computed by the author.

\subsection{Discussion}

Smart cities have been promoted by the Indian policymakers to provide 'core infrastructure; decent quality of life to its citizens; healthy environment and overall focus on sustainable and 
inclusive development.' Financial sector can be one of the key inputs in promoting smart cities development and achieving the above objectives. A major research question of this study was to examine the state of financial sector development of the cities shortlisted by Government of India to be promoted as future smart cities. The financial services index developed by the study showed sharp differences across the cities in their financial sector development. Here we focused on formal financial services provided by commercial banks which are spread widely across the states. Stock markets are not so well dispersed and also form a small proportion of the total assets of the financial sector.

As was also mentioned earlier, technological innovations are widely believed to form the foundation of smart cities. However, the use of internet still remains considerably low in these cities and in the country in general. The number of internet users according to Internet and Mobile Association of India is expected to be 500 million by June 2018 (that is, more than half of the country's population currently does not use internet) and majority of the users reside in urban areas. Internet subscribers (mobile plus landline) per 100 population as at end September was highest at 102.89 in Delhi and in the large states such as Uttar Pradesh and Bihar the figures are 17.97 and 15.26 in Bihar. Even in relatively developed and prosperous states like Karnataka and Maharashtra the number of internet subscribers per 100 population was much low at 38.27 and 38.39 respectively. One of the major determinants of technological innovation is human capital. Overall literacy rates, especially female literacy rate is still very low in some of the cities for instance in East Godavari district overall literacy rate is 71.4 with male (74.9) and female 67.8 in 2016 (DISE 2016). Also, more than the quantity of education, there are concerns on the quality of education for instance reading abilities of children.

\section{Conclusion}

As in other countries smart city mission has been launched in India as well. This study briefly examined 20 smart cities shortlisted by the Government of India and the state of financial development of these cities. Although several benchmarks have been laid down for the development of smart cities, financial sector development of the cities is not one of them. As an inclusive and developed financial system allows investment in health, education, business opportunities and promotes economic growth, it is crucial that a holistic approach to smart cities is adopted. 
This study therefore, focused on twenty cities initially shortlisted by the government and developed a composite financial index (for 18 cities) covering the dimensions of access and usage of financial services. The results of the study revealed high inter-state and intra-state inequality as the cities with high FSI values and those with low FSI values are both located in the developed western and southern states. A similar mixed picture emerges even for the less developed low income states such as Madhya Pradesh. The study also highlighted large interstate variations across the smart cities in financial development. A policy implication drawing from this research is that for a 'smart city' to develop the government should pay attention not only to adequate availability of water supply, electricity, IT facilities, governance and environment, but also should consider a developed financial system which provides access to financial services and facilitates investment in health, education and businesses and strengthening human capital. 


\section{References}

Albino, V., et al. (2015). "Smart Cities: Definitions, Dimensions, Performance, and Initiatives." Journal of Urban Technology 22(1): 3-21.

Alok, V. N. and A. Vashist (2017). "Financing Smart Cities in India." Indian Journal of Public Administration.

Anttiroiko, A. and P. Valkama (2014). "Smart cities in the new service economy: building platforms for smart cities." AI \& Society 29(3): 323-334.

Arora, R. (2017). Financial Inclusion: Understanding Concept, Barriers and Measurement, in Financial inclusion for poverty alleviation: Banking on the unbanked, Routledge, Edts. Mohammed, E.Y. and Uraguchi, Z. B.

Bakici, T., et al. (2013). "A Smart city initiative: the case of Barcelona." Journal of Knowledge Economy 4: 135-148.

Becker, B. (2006). City size and financial development, Swedish Institute for Financial Research. No 46.

Bélissent, J. (2010). "Getting Clever About Smart Cities: New Opportunities Require New Business Models ". Retrieved January 3, 2018, from http://193.40.244.77/iot/wpcontent/uploads/2014/02/getting_clever_about_smart_cities_new_opportunities.pdf.

Bodenhorn, H. and D. Cuberes (2010). Financial Development and City Growth: Evidence from North Eastern American Cities, 1790-1870 Barcelona, Institut d'Economia de Barcelona, Universitat de Barcelona.

Bruhn, M., \& Love, I. (2014). The real impact of improved access to finance: Evidence from Mexico. The Journal of Finance, 69(3), 1347-1376. doi:10.1111/jofi.12091

Chourabi,H, Gil-Garcia, R.J, Pardo, T.A, Nam, T.,Mellouli, S, Scholl, H.J., Walker, S., Nahon, K. (2012). Understanding Smart Cities: An Integrative Framework, 45th Hawaii International Conference on System Sciences.

Cosgrave, E., et al. (2013). "Living Labs, Innovation Districts and Information Marketplaces: A Systems Approach for Smart Cities." Procedia 16: 668 - 677.

Cruz, C. O. and J. M. Sarmento (2017). "Reforming traditional PPP models to cope with the challenges of smart cities." Competition and Regulation in Network Industries 8(1-2): 94114.

Dabla-Norris, E., et al. (2015). Identifying Constraints to Financial Inclusion and Their Impact on GDP and Inequality: A Structural Framework for Policy. IMF Working Paper, WP/15/22. Washington DC, International Monetary Fund.

D'Onofrio, A. and P. Murro (2013). "Local banking development and income distribution across Italian provinces." Retrieved October 3, 2013, from http://www.ecineq.org/ecineq_bari13/FILESxBari13/CR2/p244.pdf. 
Destefanis, S., et al. (2014). "Financial development and local growth: evidence from highly disaggregated Italian data." Applied Financial Economics 24(24): 1605-1615.

Fafchamps, M. and M. Schündeln (2013). "Local financial development and firm performance: Evidence from Morocco." Journal of Development Economics 103: 15-28.

Francis, E., et al. (2017). Digital Credit: A Snapshot of the Current Landscape and open Research Questions.

Flug, K., et al. (1998). "Investment in education: do economic volatility and credit constraints matter?" Journal of Development Economics 55(2): 465-481.

Government of India (2016). Smart Cities Mission retrieved from http://smartcities.gov.in/content/smart_solution.php\#

Gomber, P., et al. (2017). "Digital Finance and FinTech: current research and future research directions." Journal of Business Economics 87: 537-580.

Guiso, L., Sapienza, P, and Zingales, L. (2004). "The Role of Social Capital in Financial Development." American Economic Review, 94(3): 526-556.

Haque, U. (2012). Surely there's a smarter approach to smart cities? April 2012. Available at http://www.wired.co.uk/article/potential-of-smarter-cities-beyond-ibm-and-cisco

Hoelscher, K. (2016). "The evolution of the smart cities agenda in India." International Area Studies Review 19(1): 28-44.

Huston, S., et al. (2015). "'Smart' sustainable urban regeneration: Institutions, quality and financial innovation." Cities 48(66-75).

Imboden, K. (2005). "Building Inclusive Financial Sectors: The Road to Growth and Poverty Reduction." Journal of International Affairs 58 (2 ): 65-86.

Jayaratne, Jith and Strahan, Philip E. (1996). "The Finance-Growth Nexus: Evidence from Bank Branch Deregulation,” The Quarterly Journal of Economics, 1996, 111 (3), 639-670.

Krebs, T., et al. (2007). Human Capital, Trade Liberalization and Income Risk. World Bank Policy Research Working Paper WPS4276. Washington DC, World Bank.

Levine, R. (1997). "Financial Development and Economic Growth: Views and Agenda." Journal of Economic Literature 35(2): 688-726.

Li, Y., et al. (2015). "The development of smart cities in China ". Retrieved March 2, 2018, from http://web.mit.edu/cron/project/CUPUM2015/proceedings/Content/pss/291_li_h.pdf.

Lucchetti, R., Papi, L. and Zazzaro, A. (2001) Banks' inefficiency and economic growth: a micro-macro approach, Scottish Journal of Political Economy, 48, 400-24.

doi:10.1111/1467-9485.00206. 
Naranapawa, A and Arora, R.U. (2014). Does trade liberalisation promote regional disparities? Evidence from a multiregional CGE model of India, World Development, Volume 64, December, 339-349, DOI: 0.1016/j.worlddev.2014.06.001

Neirotti, P., et al. (2014). "Current trends in Smart City initiatives: Some stylised facts." Cities 38: 25-36.

Oliveira, A. and M. Campolargo (2015). "From Smart Cities to Human Smart Cities." Retrieved March 1, 2018, from https://www.infona.pl/resource/bwmeta1.element.ieee-art000007070095.

Pan, F. and B. Yang (2018). "Financial development and the geographies of startup cities: evidence from China." Small Business Economics. from https://doi.org/10.1007/s11187-0179983-2.

Petersen, M. and R. Rajan (2002). "Does Distance Still Matter? The Information Revolution in Small Business Lending." The Journal of Finance 57(6): 2533-2570.

Radcliffe, D. and R. Voorhies (2012). "A Digital Pathway to Financial Inclusion." Retrieved Feb 2, 2018, from https://papers.ssrn.com/sol3/papers.cfm?abstract_id=2186926.

Sahay, R., et al. (2015). Financial Inclusion: Can it Meet Mutiple Macroeconomic Goals? IMF Staff Discussion Note, SDN/15/17 Washington DC, International Monetary Fund.

Sarma, M. and J. Pais (2011). "Financial Inclusion and Development." Journal of International Development 23: 613-628.

Shapiro, J. M. (2006). "Smart Cities: Quality of Life, Productivity, and the Growth Effects of Human Capital." The Review of Economics and Statistics 88(2): 324-335.

Smart Cities Stakeholder Platform (2013). Financing Models for Smart Cities, European Commission.

Thangavelu, S. M., Jiunn, A. B. and Ang, J. B. (2004) Financial development and economic growth in Australia: an empirical analysis, Empirical Economics, 29, 247-60. doi:10.1007/s00181-003-0163-7.

UN (2013). A Renewed Global Partnership for Development. New York, UN System Task Team on the Post-2015 UN Development Agenda, United Nations.

UNDP (2009). Human Development Report 2009: Overcoming barriers: Human mobility and development. New York, United Nations Development Programme.

Vadgama, C., et al. (2015). "Smart Funding Options for Developing Smart Cities: A Proposal for India." Indian Journal of Science and Technology 8(34): 1-12.

Vaona, A. (2008) Regional evidence on financial development, finance term structure and growth, Empirical Economics, 34, 185-201. doi:10.1007/s00181-007-0153-2. 
Winters, J. V. (2011). "Why are smart cities growing? Who moves and who stays." Journal of Regional Science 51(2): 253-270.

Zhang, Q. \& Posso, A. (2017): Thinking inside the Box: A Closer Look at Financial Inclusion and Household Income, The Journal of Development Studies, DOI:

10.1080/00220388.2017.1380798 